\title{
Influence of specimen dimensions on bursting behaviour of rocks under true triaxial loading condition
}

\author{
S Akdag The University of Adelaide, Australia \\ M Karakus The University of Adelaide, Australia \\ G Nguyen The University of Adelaide, Australia \\ A Taheri The University of Adelaide, Australia
}

\begin{abstract}
Rockburst is a sudden violent ejection of rock fragments from the free surface created during excavation of a tunnel, drifts or any underground openings. Due to deep mining and/or tunnelling activities under high pressure and temperature conditions, the occurrence of rockburst is getting more frequent and prevalent, which may result in catastrophic failures and fatalities. Therefore, understanding the mechanism of rockburst phenomenon has a paramount importance for safe underground construction. In the last decade, true triaxial testing system has been widely used to understand rockburst by replicating in situ stress states before and after the excavation in the laboratory. In these tests, rectangular prism or cubic specimens are commonly used. However, no specifications for specimen dimensions and aspect ratios are recommended by the International Society for Rock Mechanics (ISRM) or the American Society for Testing and Materials (ASTM) for a standard rockburst test. In this study, we have collected a comprehensive database from the literature to evaluate influence of specimen dimensions on results of rockburst test for a potential development of standard samples dimensions. The effects of dimensions of rectangular rock prisms with different height-to-width $(H / W)$, height-to-thickness $(H / T)$ and width-to-thickness $(W / T)$ ratios on the rockburst failure were investigated and the failure modes with respect to various aspect ratios were evaluated in terms of stored strain energy in $p$-q space. It was found that, $H / W$ ratio has the most significance influence on the failure mode regardless of the stress states. Dynamic failure of the specimens was transformed from spalling and splitting (local rock ejection) to slabbing and bursting (full-face bursting) when the H/W ratio increases and bursting behaviour becomes more violent.
\end{abstract}

Keywords: rockburst, strainburst, true triaxial test, failure mode, specimen height-to-width ratio

\section{Introduction}

Due to the depletion of ore deposits closer to the surface, deep mining operations are becoming more common in the mining industry. Increase in mining depth results in increased in situ stresses. As a rule of thumb, in any underground operations over 1,000 m depth, rockburst incidents are expected. When the induced principal stress $\sigma_{1}$ due to creation of underground openings reaches to rock mass strength $\sigma_{\mathrm{cm}}$, rock mass will fail in a way that rock fragments from the construction face are ejected violently because of the release of a large amount of stored strain energy. Rockburst can kill people and cause injuries, as well as it can cause a temporary or permanent cease of mining or tunnelling operations. Therefore, it is significant to understand the mechanisms behind rockburst, which is considered as the biggest unresolved problem in deep underground excavations (He et al. 2016) for safer underground construction designs in greater depths.

In the last few decades, many studies based on experimental, theoretical and numerical approaches have been carried out to resolve the rockburst phenomena (Cook 1966; Curtis 1981; Blake \& Hedley 1992; Ortlepp \& Stacey 1994; Linkov 1996; Wang \& Park 2001). It is mostly suggested that rockburst is a function of both the stored strain energy in the rock mass and rate of energy release at failure. Due to the complexity in energy concept in rockburst occurrence, several approaches have been proposed to control and forecast rockbursts 
(Barton et al. 1974; Heunis 1980; Kidybinski 1981; Kaiser et al. 1996; Cai \& Champaigne 2009; Li 2010; Kaiser \& Cai 2012; Cai 2013). He et al. (2012a) developed a constant-resistance and large-deformation bolt (CRLDB) to control and prevent rockburst occurrence. CRLDBs absorb the deformation energy of host rocks with large deformation by elongating constantly to adapt itself against the external loading. Xu et al. (2016) installed a microseismic monitoring system to forecast the occurrence and location of rockburst during the tunnel boring machine (TBM) and drilling and blasting (D\&B) tunnelling advancement. They assessed the microseismic data to be used as a precursor prior to the occurrence of rockbursts in the deep tunnels at the Jinping II hydropower station and concluded that it is necessary to identify and forecast possible rockburst regions via microseismic monitoring technique during deep engineering constructions under high geo-stress conditions in which equipment damage and injury of personnel could be minimised.

Numerous experimental studies were performed by researchers to understand the rockburst mechanism. True triaxial loading system was developed to investigate rock behaviour under three independently applied principal stresses, $\sigma_{1}>\sigma_{2}>\sigma_{3}$ (Mogi 1971; Michelis 1985; Takahaski \& Koide 1989; Wawersik et al. 1997; Haimson \& Chang 2000; Cheon et al. 2006). In order to better understand the rockburst characteristics, a novel true triaxial testing machine was developed by He et al. (2010) at the State Key Laboratory for Geomechanics and Deep Underground Engineering in Beijing, China. In this system, rockburst test is conducted by abruptly dropping the loading plate from one of the rectangular prism's face which is usually in the direction of minor principal stress and thus the specimen surface is free of any loading condition that is equivalent to creation of excavation in underground. Consequently, it is possible to replicate the stress redistribution around an underground opening via this test system. A series of experiments on different types of rock specimens have been conducted in terms of various stress paths to clarify the rockburst mechanism under true triaxial loading/unloading conditions (He et al. 2010, 2012a, 2012b; Zhao et al. 2014; Gong et al. 2015; Li et al. 2015). Rectangular or cubical rock specimens have been used for true triaxial testing. However, studies regarding the influence of rock sample dimensions on rockburst characteristics are very limited.

It has been well understood that size or scale effect poses a significant role on the mechanical behaviours of rocks. Influence of specimen dimensions and slenderness ratio (i.e. height-to-width $(\mathrm{H} / \mathrm{W})$ on strength and failure modes has been studied by many researchers via conventional uniaxial or triaxial compression tests (Mogi 1962; Bieniawski 1968; Hudson et al. 1972; Bazant \& Xiang 1997; Li et al. 2011). Hudson et al. (1972) reported that decreasing the $\mathrm{H} / \mathrm{W}$ ratio results in increased failure strength under uniaxial compression, while on the contrary, the post peak stress-strain curves showed less steep trend. Martin and Maybee (2000) discussed the failure modes in pillars of some Canadian hard rock mines. They found that slabbing and spalling are the most dominant failure types when the ratio of pillar width to pillar height $\left(W_{p} / W_{h}\right)$ is less than 2.5. Size effect on rectangular prismatic specimens was investigated by Li et al. (2011). In their research, Iddefjord granite samples from Norway were loaded under uniaxial compression and it was observed that failure mode was transformed from shear to slabbing in case of reducing the $\mathrm{H} / \mathrm{W}$ ratio to 0.5 . They also indicated that slabbing occurs parallel to the loading direction with a strength of $60 \%$ of uniaxial compressive strength. Recently, Manouchehrian and Cai (2016) investigated the unstable rock failure under uniaxial and polyaxial loading-unloading conditions by using finite element method (FEM). They proposed two parameters; loading system reaction intensity (LSRI) and transferred energy ratio (TER) to be used as an indicator of unstable failure. According to the numerical analyses results, it was indicated that the higher the $\mathrm{H} / \mathrm{W}$ ratio, the more violent the failure is. It was also found that increasing the intermediate principal stress results in less violent failure based on the release of excessive energy. However, the effect of specimen dimension ratio on burst behaviour under true triaxial loading still remains unclear. Therefore, this research aims at evaluating the influence of rectangular rock prisms with different height-to-width (H/W), height-to-thickness $(\mathrm{H} / \mathrm{T})$ and width-to-thickness $(\mathrm{W} / \mathrm{T})$ on the failure mode using strain energy concept to identify critical dimensions of rock specimens to be used in true triaxial rockburst tests (Figure 1). 

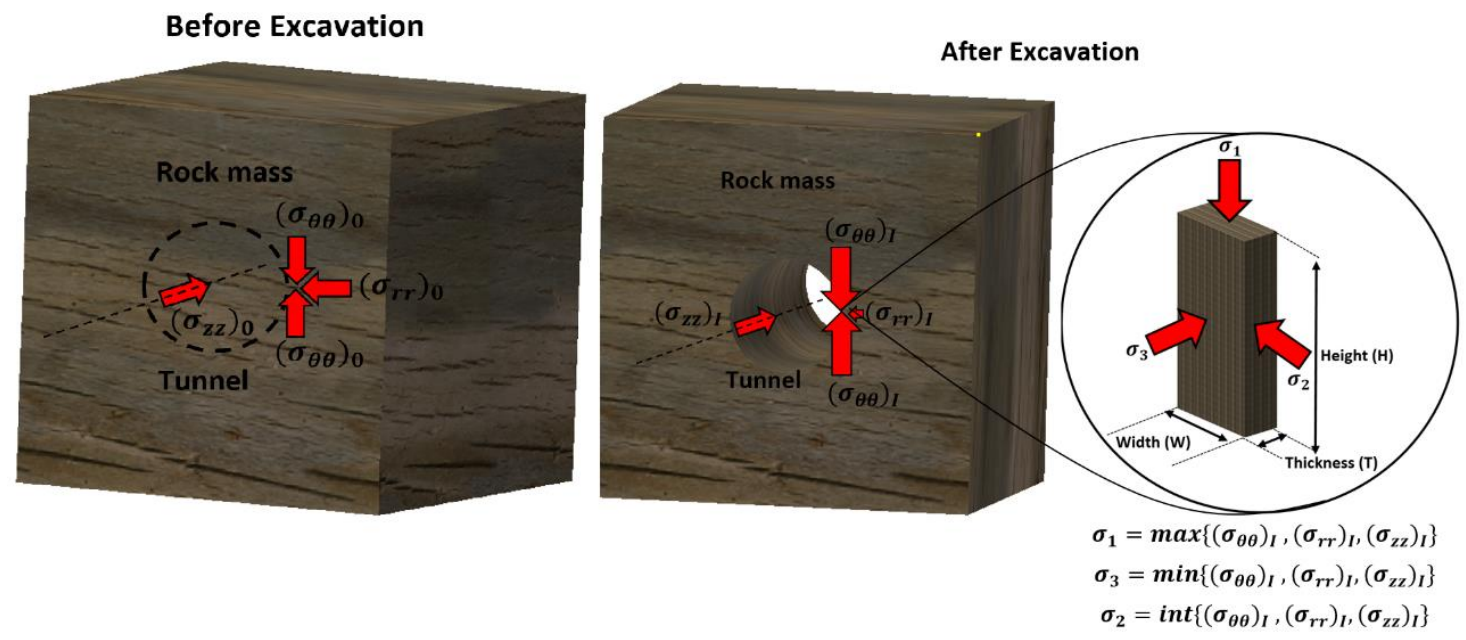

Figure 1 Illustration of stress state change for rock on the underground opening wall before and after excavation

\section{Rockburst tests database}

In this section, the true triaxial rockburst testing process and the rockburst tests results available in the literature are collected and discussed briefly. Firstly, the true triaxial loading system is introduced. Subsequently, the rockburst test results with geometrical properties of the rock specimens are presented.

\subsection{True triaxial testing system}

In situ stresses are governed by the polyaxial stress condition in underground prior to excavation. The original stresses in rock mass are disturbed by the man-made excavations. The radial/minimum principal stress $\left(\sigma_{3}\right)$ abruptly reduces to zero, while intermediate principal stress $\left(\sigma_{2}\right)$ remains unchanged and the tangential/maximum principal stress $\left(\sigma_{1}\right)$ increases after creation of an excavation. When the induced stresses reach the rock mass strength, failure takes place under biaxial loading condition on the walls, as shown in Figure 1.

In order to simulate the stress path of rocks under a true triaxial loading condition, a testing machine was developed by $\mathrm{He}$ et al. (2010). This hydraulic test apparatus is composed of main loading part, hydraulic controlling unit including data acquisition system, acoustic emission (AE) monitoring system, high speed digital camera, and thermal monitoring system (Figure 2).

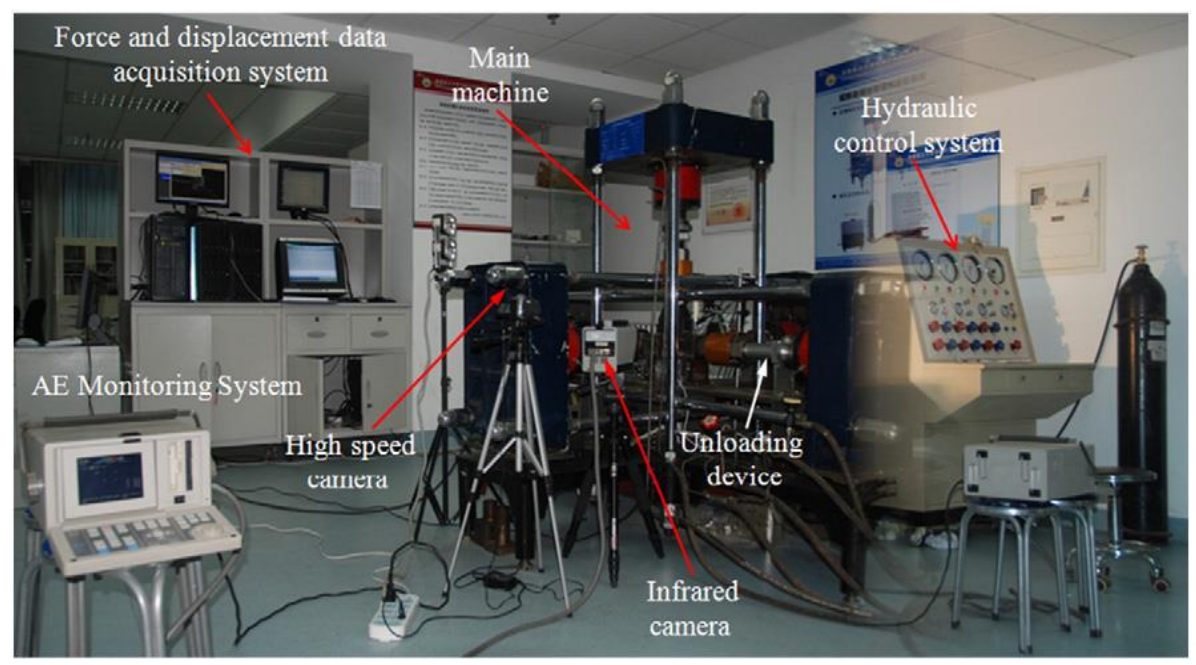

Figure 2 A true triaxial testing apparatus for rockburst (He et al. 2015) 
The testing procedure can be summarised as follows:

- Rectangular or cubical rock specimens are loaded independently in three principal stress directions progressively to the desired in situ stress level.

- The stress state is retained for a while to provide in situ stress state condition on the rock specimen.

- A sudden drop on one of the loading face where minimum principal stress $\left(\sigma_{3}\right)$ is acting, while intermediate principal stress $\left(\sigma_{2}\right)$ is kept constant and maximum principal stress $\left(\sigma_{1}\right)$ is increased until rockburst occurrence.

Therefore, tangential and radial stresses change due to an excavation can be simulated via true triaxial testing procedure in laboratory scale. A designed stress path, schematic illustration of testing procedure and side view of unloading process are shown in Figure 3.
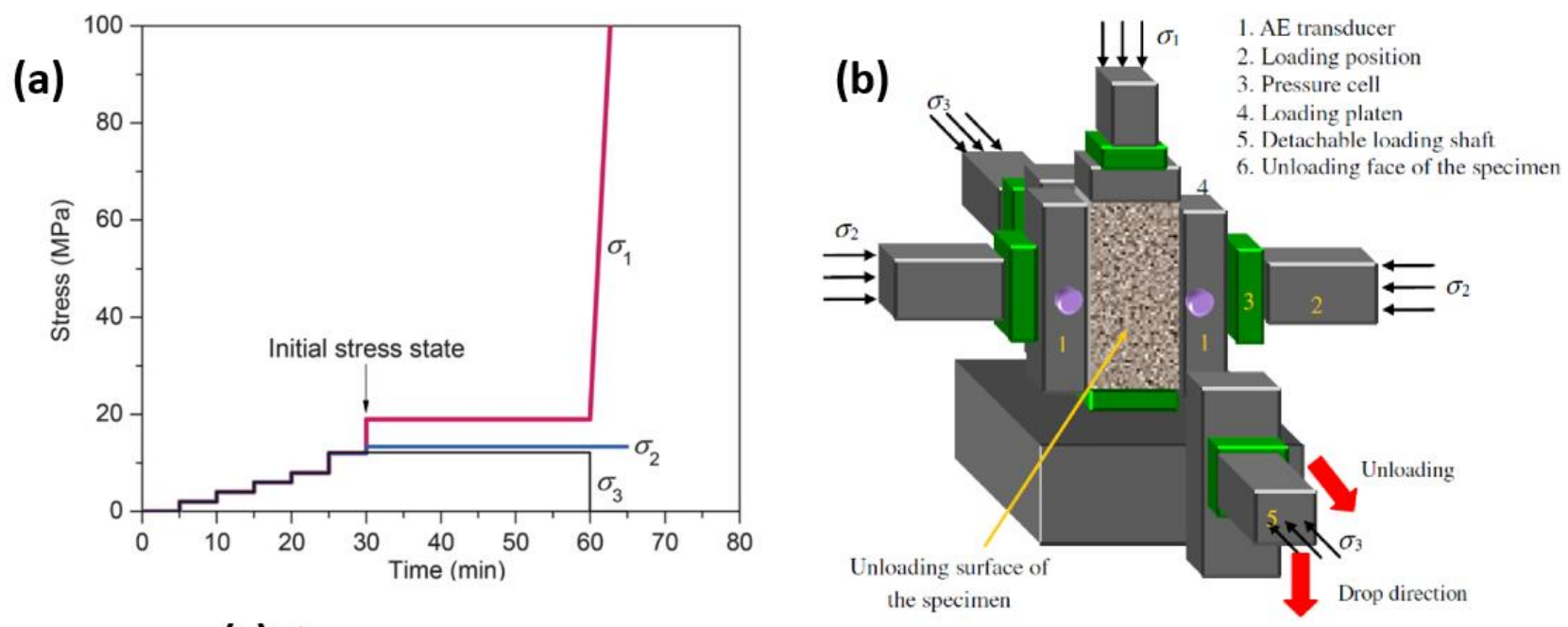

(c)

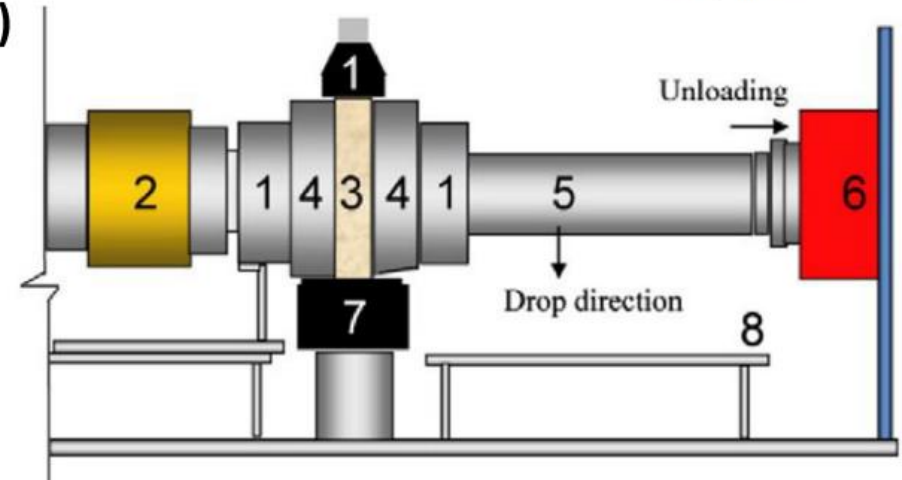

1 Pressure head; 2 Load cell; 3 Rock sample; 4 Loading plate;

5 Dowel steel; 6 Cylinder; 7 Base plate; 8 Support frame

Figure 3 Illustration of (a) designed stress path; (b) schematic view of testing process; (c) side view of unloading system (after He et al. 2010)

\subsection{Database with test results}

An extensive literature review was conducted through various studies related to true triaxial rockburst tests and a comprehensive database was constructed with 67 rockburst tests. Rock types being used for the tests were granite (33), sandstone (14), marble (7), and a few others. Distribution of the tests with respect to rock types can be seen in Figure 4. 


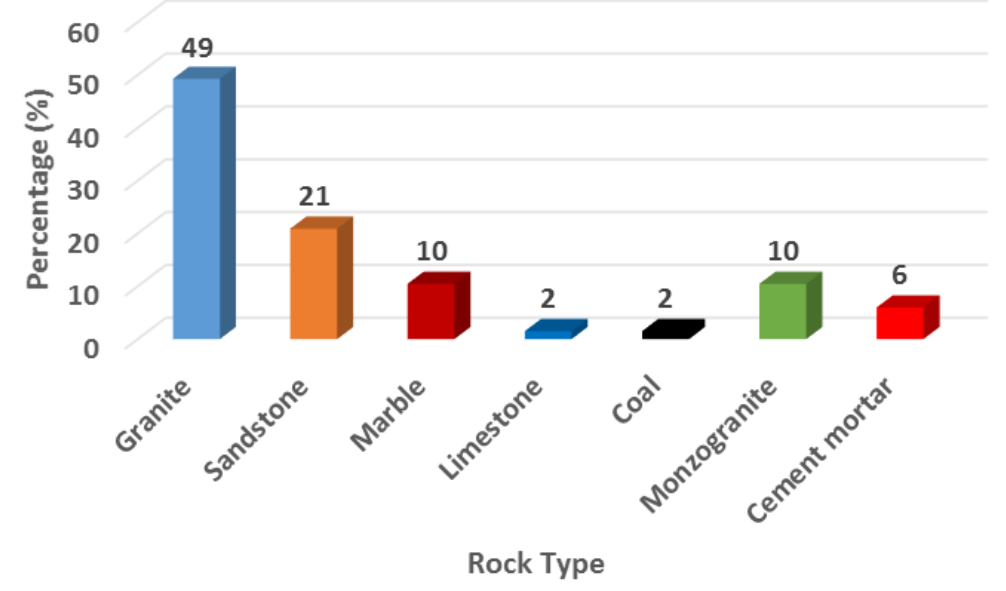

Figure 4 Distribution of rock types in true triaxial test database

Table 1 shows the dimensions and stress state at failure for the true triaxial tests. Due to the large amount of data, all tests in the database are not included in this paper. The average specimen height is $117.5 \mathrm{~mm}$ with a minimum of $60.7 \mathrm{~mm}$ and a maximum of $151.8 \mathrm{~mm}$; the width one face of which is unloaded abruptly is $73.31 \mathrm{~mm}$ in average with a minimum of $38.85 \mathrm{~mm}$ and a maximum of $100 \mathrm{~mm}$. Specimen thickness has an average of $54.3 \mathrm{~mm}$ with a minimum of $19.2 \mathrm{~mm}$ and a maximum of $100 \mathrm{~mm}$. Average specimen volume is $495.9 \mathrm{~cm}^{3}, 80.4 \mathrm{~cm}^{3}$ in minimum and $1,000 \mathrm{~cm}^{3}$ in maximum. The corresponding face in which $\sigma_{3}$ is removed to simulate excavation has an average surface area of $83.8 \mathrm{~cm}^{2}$ with a minimum of $36.8 \mathrm{~cm}^{2}$ and a maximum of $100 \mathrm{~cm}^{2}$.

\section{Results and discussion}

In geomechanics, failure type poses a critical role for underground constructions. In deep mining and/or tunnelling, it is more frequent to encounter failures in slabbing or rockbursting rather than in shearing, splitting or local spalling of rock fragments (Fairhurst \& Cook 1966). According to Palmstrom and Stille (2007), shear failure generally occurs along a conjugate fracture plane whereas slabbing and rockburst, in which crack growth states are similar, take place as more violent ejection of large rock fragments. These main rock failure modes for underground openings are summarised by Hoek et al. (1995) included in Figure 5.

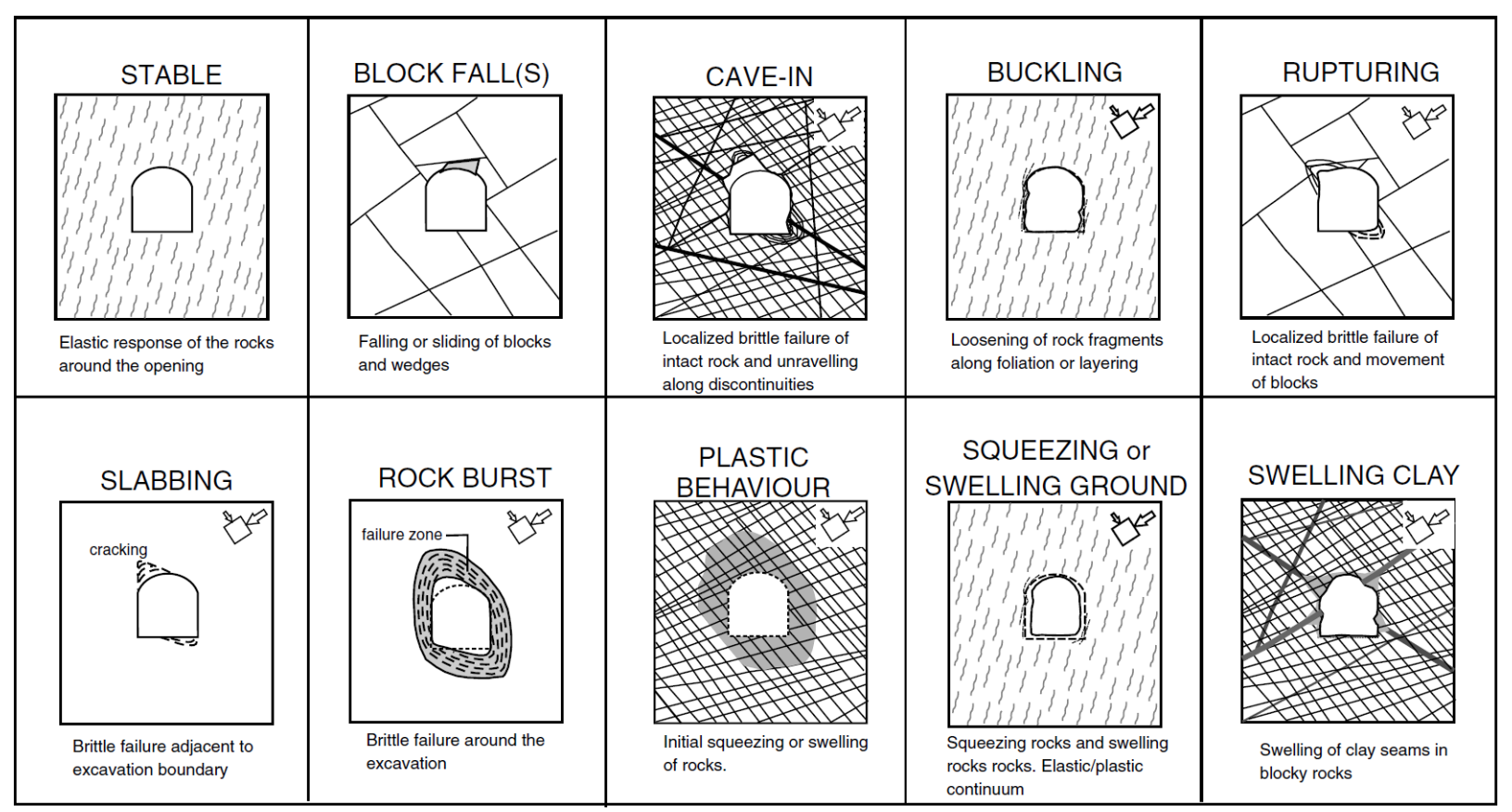

Figure 5 Rock failure types for underground excavations (Palmstrom and Stille 2007) 
Dimensions and critical stress state at failure for true triaxial tests

\begin{tabular}{|c|c|c|c|c|c|c|c|c|c|c|}
\hline \multirow{2}{*}{ Rock material } & \multirow{2}{*}{$\begin{array}{c}\text { Specimen size } \\
{[\mathrm{mm} \times \mathrm{mm} \times \mathrm{mm}]}\end{array}$} & \multicolumn{3}{|c|}{ Stress state at failure (MPa) } & \multirow{2}{*}{$\sigma_{1} / \sigma_{c}$} & \multirow{2}{*}{$\left(\sigma_{1}+\sigma_{2}\right) / \sigma_{c}$} & \multirow{2}{*}{$\left(\sigma_{1}-\sigma_{2}\right) / \sigma_{c}$} & \multirow{2}{*}{$\begin{array}{c}\text { Rockburst } \\
(\mathrm{Y} / \mathrm{N})\end{array}$} & \multirow{2}{*}{ Failure mode } & \multirow{2}{*}{ References } \\
\hline & & $\sigma_{1}$ & $\sigma_{2}$ & $\sigma_{3}$ & & & & & & \\
\hline Granite & \multirow{5}{*}{$150 \times 60 \times 30$} & 130.1 & 60.8 & 0 & 0.99 & 1.46 & 0.53 & $Y$ & Rockburst & \multirow{5}{*}{$\begin{array}{l}\text { He et al. } \\
(2009)\end{array}$} \\
\hline Sandstone & & 109.4 & 73.2 & 0 & 1.05 & 1.76 & 0.35 & Y & Rockburst & \\
\hline Limestone & & 110.9 & 61.9 & 0 & 1.42 & 2.22 & 0.63 & $\mathrm{~N}$ & Slabbing & \\
\hline Marble & & 104.1 & 39.4 & 0 & 1.30 & 1.79 & 0.81 & $\mathrm{~N}$ & Slabbing & \\
\hline Coal & & 17.6 & 8.1 & 0 & 1.17 & 1.71 & 0.63 & $Y$ & Rockburst & \\
\hline Marble & $100.6 \times 39.8 \times 20.1$ & 50 & 12 & 0 & 0.86 & 1.07 & 0.66 & $\mathrm{~N}$ & Spalling & $\begin{array}{l}\text { Coli et al. } \\
(2010)\end{array}$ \\
\hline \multirow{2}{*}{ Sandstone } & $150.4 \times 61.8 \times 29.7$ & 114.4 & 40.6 & 0 & 1.63 & 2.21 & 1.05 & Y & Rocburst & \multirow{2}{*}{$\begin{array}{l}\text { He et al. } \\
\text { (2012b) }\end{array}$} \\
\hline & $150.6 \times 60.5 \times 30.5$ & 113.5 & 65.6 & 0 & 1.62 & 2.56 & 0.68 & $Y$ & Rockburst & \\
\hline \multirow{2}{*}{ Marble } & $99.7 \times 38.9 \times 20.8$ & 76.8 & 33.8 & 0 & 1.32 & 1.91 & 0.74 & $Y$ & Rockburst & \multirow{2}{*}{$\begin{array}{l}\text { He et al. } \\
(2010)\end{array}$} \\
\hline & $101.1 \times 41.6 \times 19.2$ & 61 & 14.2 & 0 & 1.05 & 1.30 & 0.81 & $Y$ & Rockburst & \\
\hline \multirow{2}{*}{ Granite } & $150.1 \times 60.1 \times 30.1$ & 117.1 & 39.0 & 0 & 1.62 & 2.15 & 1.08 & Y & Rockburst & \multirow{2}{*}{$\begin{array}{l}\text { Zhao et al. } \\
\text { (2014) }\end{array}$} \\
\hline & $150.2 \times 60.1 \times 30.2$ & 130.9 & 38.8 & 0 & 1.93 & 2.51 & 1.36 & Y & Rockburst & \\
\hline \multirow{4}{*}{ Monzogranite } & $150.7 \times 60.9 \times 30.8$ & 159.2 & 13.7 & 0 & 1.16 & 1.26 & 1.06 & $Y$ & Rockburst & \multirow{4}{*}{$\begin{array}{l}\text { Zhao and } \\
\text { Cai (2015) }\end{array}$} \\
\hline & $120.5 \times 60.9 \times 30.8$ & 148.2 & 15 & 0 & 0.98 & 1.08 & 0.88 & Y & Slabbing (local rock flake ejection) & \\
\hline & $90.7 \times 60.9 \times 30.8$ & 142.3 & 14.7 & 0 & 0.87 & 0.96 & 0.78 & $\mathrm{~N}$ & Shearing & \\
\hline & $60.7 \times 60.7 \times 30.7$ & 186.8 & 13.5 & 0 & 1.00 & 1.08 & 0.93 & $\mathrm{~N}$ & Shearing & \\
\hline \multirow{2}{*}{ Granite } & $150.5 \times 59.9 \times 28.8$ & 121.5 & 11.9 & 0 & 2.03 & 2.22 & 1.83 & Y & Slabbing & \multirow{2}{*}{$\begin{array}{l}\text { He et al. } \\
(2015)\end{array}$} \\
\hline & $150.4 \times 60.2 \times 29.5$ & 102.5 & 11.5 & 0 & 1.71 & 1.90 & 1.52 & Y & Slabbing & \\
\hline Granite & \multirow{3}{*}{$100 \times 100 \times 100$} & 180 & 10 & 0 & 1.29 & 1.37 & 1.22 & $\mathrm{~N}$ & Splitting & \multirow{3}{*}{$\begin{array}{l}\text { Li et al. } \\
\text { (2015) }\end{array}$} \\
\hline Sandstone & & 81 & 10 & 0 & 1.40 & 1.57 & 1.23 & $\mathrm{Y}$ & Slabbing & \\
\hline Cement mortar & & 28 & 10 & 0 & 1.05 & 1.42 & 0.67 & $\mathrm{~N}$ & Spalling & \\
\hline \multirow{4}{*}{ Granite } & $150.7 \times 60.9 \times 30.8$ & 159.2 & 13.7 & 0 & 0.98 & 1.07 & 0.90 & Y & Rockburst & \multirow{4}{*}{$\begin{array}{l}\text { Zhao and } \\
\text { He (2016) }\end{array}$} \\
\hline & $120.6 \times 60.9 \times 30.7$ & 170.7 & 13.9 & 0 & 1.05 & 1.14 & 0.97 & Y & Rockburst with tensile crack & \\
\hline & $90.6 \times 60.7 \times 30.8$ & 163.9 & 13.8 & 0 & 1.01 & 1.10 & 0.93 & $\mathrm{~N}$ & Shearing with tensile crack & \\
\hline & $60.7 \times 60.7 \times 30.7$ & 186.8 & 13.5 & 0 & 1.15 & 1.24 & 1.07 & $\mathrm{~N}$ & Shearing with no tensile crack & \\
\hline
\end{tabular}


The relationship between elastic strain energy density and the dissipated energy density per unit volume of rock mass under loading and unloading conditions can be seen in Figure 6 . The zones under the unloading stress-strain curve and between the loading and unloading stress-strain curve represent the elastic strain energy density and the dissipated energy density, respectively, at a given stage of deformation. In this study, elastic strain energy density per unit rock volume calculations were conducted on the available database with respect to different $\mathrm{H} / \mathrm{W}$ ratios.

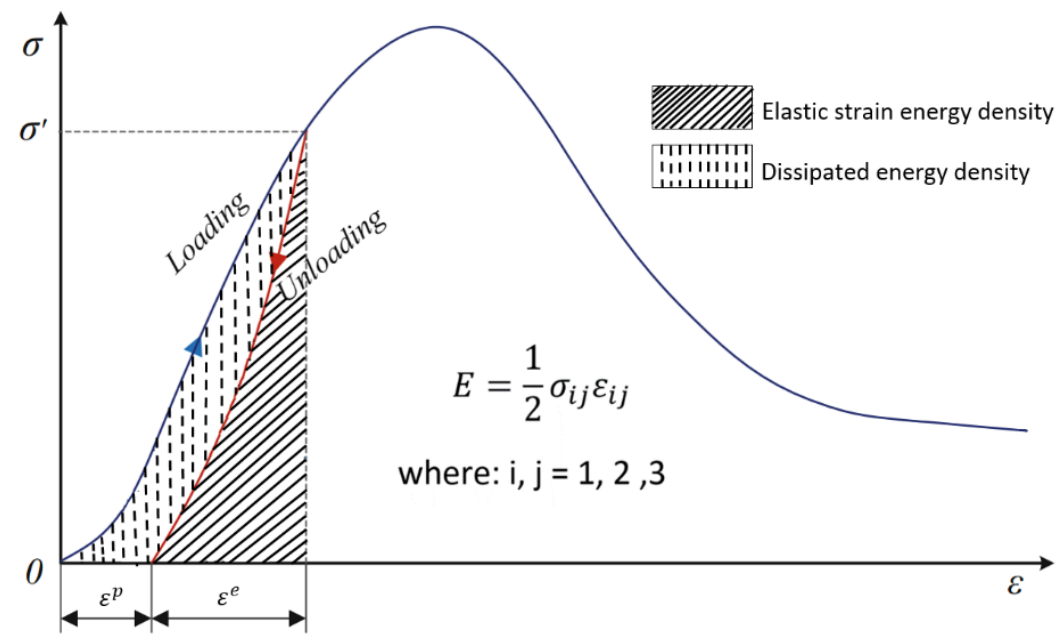

Figure 6 Enclosed areas for corresponding elastic energy density and dissipated energy density per unit rock volume

\subsection{Influence of specimen dimensions on rockbursting behaviour}

The elastic strain energy densities per unit rock volume (shown in Figures 7-9) within the specimens at which rockburst occurred, were calculated for various $\mathrm{H} / \mathrm{W}, \mathrm{H} / \mathrm{T}$ and $\mathrm{W} / \mathrm{T}$ ratios. Figures 7-9 comprise the test results of granite, sandstone, monzogranite and other rock types in which rockburst occurred and these figures show the effects of ratios of $H / W, H / T$, and $W / T$ on rockburst behaviour. The stresses in Figures 7-9 are at the onset of bursting as collected from the experiments.

The energy calculations are constituted by using the unified co-ordinates in $p$ - $q$ space that are based on stress invariants. The co-ordinates $p$ and $q$ are defined in Equations (1) and (2) respectively.

$$
\begin{gathered}
q=\sqrt{3 J_{2}}=\sqrt{\frac{\left(\sigma_{1}-\sigma_{2}\right)^{2}+\left(\sigma_{2}-\sigma_{3}\right)^{2}+\left(\sigma_{1}-\sigma_{3}\right)^{2}}{2}} \\
p=\frac{I_{1}}{3}=\frac{\sigma_{1}+\sigma_{2}+\sigma_{3}}{3}
\end{gathered}
$$

where:

$\mathrm{q}=$ the deviatoric stress component.

$\mathrm{p}=$ the hydrostatic stress component.

$12=$ the second invariant of stress deviator tensor.

$11=$ the first invariant of stress tensor (Chen \& Han 1988). 

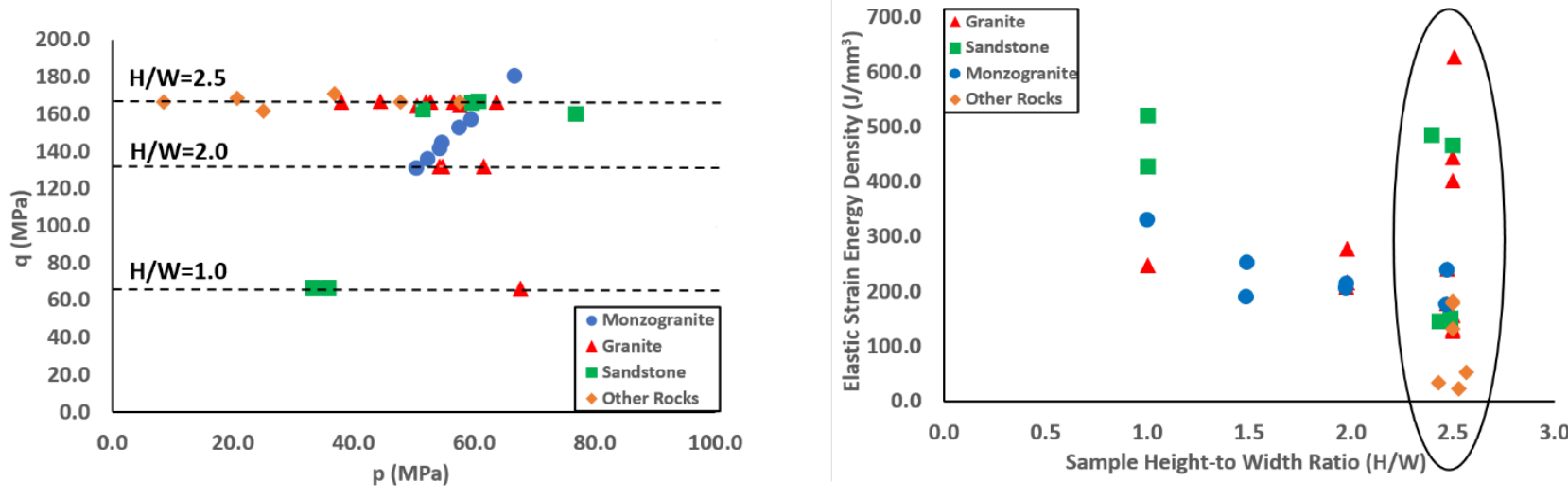

Figure 7 Influence of $\mathrm{H} / \mathrm{W}$ ratio of different rock samples on bursting behaviour based on elastic strain energy density
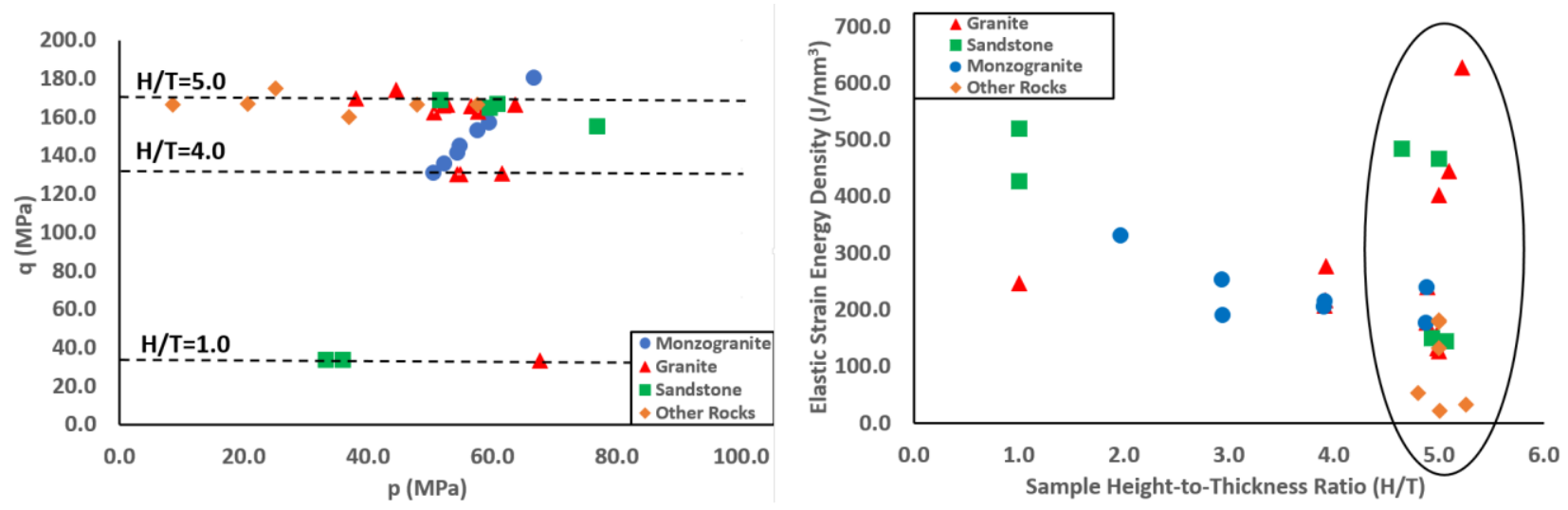

Figure 8 Influence of $\mathrm{H} / \mathrm{T}$ ratio of different rock samples on bursting behaviour based on elastic strain energy density
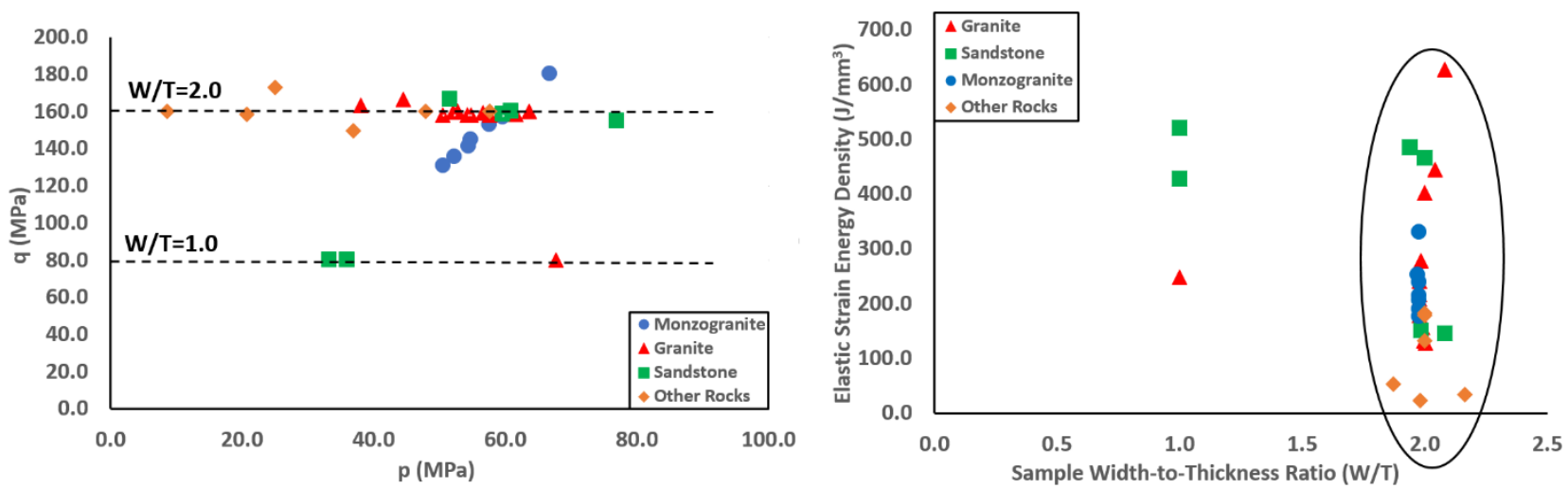

Figure 9 Influence of $\mathrm{W} / \mathrm{T}$ ratio of different rock samples on bursting behaviour based on elastic strain energy density

In Figure 7, it can be clearly seen that when the H/W ratio is greater than 2, rockbursting behaviour is more frequently encountered. When the $\mathrm{H} / \mathrm{W}$ ratio is 2.5 , rockbursting with violent large rock fragment ejection occurs due to the high amount of strain energy stored within the specimens. The elastic strain energy density per unit rock volume which is directly related to the stored strain energy within the rock specimen varies between 20 and $600 \mathrm{~J} / \mathrm{mm}^{3}$ in the created database. The data points for various rocks centre around the H/W ratio of 2.5 which indicates that full-face bursting behaviour is more common as a failure mode (Figure 7). As can be seen in Table 1, with a further decrease of the $\mathrm{H} / \mathrm{W}$ ratio to 1, the failure mode changes from full face bursting to spalling or shearing. The failures of the rock specimens were recorded as spalling, splitting or 
shearing when $\mathrm{H} / \mathrm{W}$ ratio decreases (Table 1). Therefore, based on the test results, the rockbursting behaviour is highly dependent on the $\mathrm{H} / \mathrm{W}$ ratio. It can be seen from Figure 8 , once $\mathrm{H} / \mathrm{T}$ ratio is greater than 4 , bursting is more frequent under true triaxial loading conditions. The decrease of H/T ratio from 4 to 1 results in a decrease of rockbursting failure type. When the ratio between width and thickness of the rectangular prism rock sample gets closer to 1 as shown in Figure 9, the rockbursting behaviour diminishes. According to the results, it is clear that the ratio of height-to-width $(H / W)$ has more significant influence on bursting behaviour than the ratios of $\mathrm{H} / \mathrm{T}$ and $\mathrm{W} / \mathrm{T}$. When the deviatoric stress level is higher than $150 \mathrm{MPa}$ and $\mathrm{H} / \mathrm{W}$ ratio is around 2.5 , rock samples are more susceptible to rockbursting behaviour. Thus, geometrical properties of rock specimens for true triaxial rockburst test have a crucial role in rockburst behaviour.

In order to classify and forecast magnitude of rockburst behaviour, various rockburst criteria have been proposed by many researchers by using strength and energy indices. In this study, criteria suggested by Barton et al. (1974) and Tao (1987) were also used to asssess the rockburst occurrence as summarised in Table 2. Major principal stress state at failure and critical failure strengths of the samples are used as indicators of predicting rockburst occurrence. Although, these indices can be used as a preliminary guideline for forecasting rockburst, the estimations for this study do not show good consistency with the true triaxial test results. It can be indicated that since these indices were constituted based on several case studies from different mine sites, it is not appropriate to use them for experimental approaches. The main reasons of this discrepancy may be the influence of discontinuities and the difference between the stress concentrations of laboratory and field conditions. Thus, in order to better forecast bursting tendency, rockburst indices should be enhanced based on a richer experimental database, which requires extensive experimental works.

Table 2 Rockburst criteria

\begin{tabular}{llllll}
\hline Rockburst criterion & $\begin{array}{l}\text { Bursting } \\
\text { index }\end{array}$ & No bursting & Weak bursting & $\begin{array}{l}\text { Moderate } \\
\text { bursting }\end{array}$ & $\begin{array}{l}\text { Strong } \\
\text { bursting }\end{array}$ \\
\hline Barton (Barton et al. 1974) & $\sigma_{1} / \sigma_{c}$ & $<0.2$ & $0.2-0.4$ & $0.4-0.6$ & $>0.6$ \\
Tao (Tao 1987) & $\sigma_{c} / \sigma_{1}$ & $>14.5$ & $14.5-5.5$ & $5.5-2.5$ & $<=2.5$ \\
\hline
\end{tabular}

\section{Conclusion}

A comprehensive database was created from the literature including various rectangular specimens used in the true triaxial tests. The influence of $\mathrm{H} / \mathrm{W}, \mathrm{H} / \mathrm{T}$, and $\mathrm{W} / \mathrm{T}$ ratios on the bursting failure was investigated. The bursting behaviour tendency was discussed by considering the elastic strain energy density within the samples at the onset of bursting.

The results indicate that specimen dimensions have a strong influence on the bursting susceptibility of rocks under true triaxial testing and $\mathrm{H} / \mathrm{W}$ ratio is the most important effect for the bursting behaviour. Bursting mode of rock specimens changes from rockbursting or slabbing to local spalling or shearing when the H/W ratio is reduced from 2.5 to 1 . Considering the elastic strain energy density within the rock specimen, the higher the $\mathrm{H} / \mathrm{W}$ ratio is, the more frequent the bursting behaviour is. The established database with rockburst tests depends on the testing of rectangular or cubical rock prisms in which geometrical instability is the major issue. However, in order to provide a better understanding for the mechanism of rockbursting, it is necessary to investigate the real site conditions as the geometrical instability effects do not exist in the field.

Although this study attempts to provide an analysis about the influence of specimen dimensions and aspect ratios in rockburst testing, more tests with a wide range of $\mathrm{H} / \mathrm{W}$ ratios should be conducted to better understand the rockburst mechanism and characteristics.

\section{Acknowledgement}

This study is an early stage of an Australian Research Council (ARC) project (ARC-LP150100539). We gratefully acknowledge supports from ARC and OZ Minerals. 


\section{References}

Barton, N, Lien, R \& Lunde, J 1974, 'Engineering classification of rock masses for the design of tunnel support', Rock Mechanics and Rock Engineering, vol. 6, pp. 189-236.

Bazant, ZP \& Xiang, Y 1997, 'Size effect in compression fracture: splitting crack band propagation', Journal of Engineering Mechanics, vol. 123 , no. 2 , pp. 162-172.

Bieniawski, ZT 1968, 'The effect of specimen size on compressive strengh of coal', International Journal of Rock Mechanics and Mining Sciences and Geomechanics Abstracts, vol. 5, no. 4, pp. 325-335.

Blake, W \& Hedley, DGF 1992, Rockburst Handbook for Ontario Hardrock Mines, s.l.:CANMET Special Report SP92-1E.

Cai, M 2013, 'Principles of rock support in burst-prone ground', Tunnelling and Underground Space Technology, vol. 36, pp. 46-56.

Cai, M \& Champaigne, D 2009, 'The art of rock support in burst-prone ground', in CA Tang (ed), Proceedings of RaSiM 7: Controlling Seismic Hazard and Sustainable Development of Deep Mines, 21-23 August 2009, Dalian, China, Rinton Press, New York, pp. 33-46.

Chen, WF \& Han, DJ 1988, Plasticity for structural engineers, Springer, New York.

Cheon, DS, Jeon, S, Park, C \& Ryu, C 2006, 'An experimental study on the brittle failure under true triaxial conditions', Tunnelling and Underground Space Technology, vol 21, pp. 448-499.

Coli, M, Livi, E, Berry, P, Bandini, A \& Jia, XN 2010, 'Studies for rockburst prediction in the Carrara marble (Italy)', in F Xie (ed), Proceeding of the 5th International Symposium on In-situ Rock Stress, 25-28 August 2010, Beijing, China, CRC Press, Boca Raton, Florida, pp. 367-373.

Cook, NG 1966, 'A note on rockburst considered as a problem of stability', Journal of South Africa Institute of Mining and Metallurgy, vol. 65, pp. 437-446.

Curtis, JF 1981, 'Rockburst phonemena in the gold mines of the Witwatersrand', Transactions of the Institution of Mining and Metallurgy, vol. 90, pp. 163-176.

Fairhurst, C \& Cook, NW 1966, 'The phenomenon of rock splitting parallel to the direction of maximum compression in the neighborhood of a surface', Proceedings of the 1st Congress on the International Society of Rock Mechanics, International Society of Rock Mechanics, Lisbon, pp. 687-692.

Gong, W, Peng, Y, Wang, H, He, MC, Sousa, L \& Wang, J 2015, 'Fracture angle analysis of rock burst faulting planes based on true-triaxial experiment', Rock Mechanics and Rock Engineering, vol. 48, pp. 1017-1039.

Haimson, B \& Chang, C 2000, 'A new true triaxial cell for testing mechanical properties of rock, and its use to determine rock strength deformability of Westerly granite', International Journal of Rock Mechanics and Mining Sciences, vol. 37, no. 1, pp. 285-296.

He, MC, Miao, JL \& Feng, JL 2010, 'Rock burst process of limestone and its acoustic emission characteristics under true-triaxial unloading conditions', International Journal of Rock Mechanics and Mining Sciences, vol. 47, pp. 286-298.

$\mathrm{He}, \mathrm{MC}$, Miao, JL, Li, DJ, Zeng, FJ \& Ma, RJ 2009, 'Characteristics of acoustic emission on experimental process of strain burst at depth', in CA Tang (ed.), Proceedings of RaSiM 7: Controlling Seismic Hazard and Sustainable Development of Deep Mines, 21-23 August 2009, Dalian, China, Rinton Press, New York, pp. 181-188.

He, MC, Nie, W, Zhao, Y \& Guo, W 2012b, 'Experimental investigation of bedding plane orientation on the rockburst behavior of sandstone', Rock Mechanics and Rock Engineering, vol. 45, pp. 311-326.

He, MC, Sousa, LR, Miranda, T \& Zhu, G 2015, 'Rockburst laboratory tests database - Application of data mining techniques', Engineering Geology, vol. 185, pp. 116-130.

He, MC, Xia, H, Jia, X, Gong, W, Zhao, F \& Liang, K 2012a, 'Studies on classification, criteria and control of rockbursts', Journal of Rock Mechanics and Geotechnical Engineering, vol. 4, pp. 97-114.

He, B, Zelig, R, Hatzor, Y \& Feng, X 2016, 'Rockburst generation in discontinuous rock masses', Rock Mechanics and Rock Engineering, pp. 1-22.

Heunis, R, 1980 'The development of rock-burst control strategies for South African gold mines', Journal of South Africa Institute of Mining and Metallurgy, vol. 80, no. 4, pp. 139-149.

Hoek, E, Kaiser, PK \& Bawden, WF 1995, Support of underground excavations in hard rock, Balkema, Rotterdam.

Hudson, JA, Crouch, SL \& Fairhurst, C 1972 'Soft, stiff and servo-controlled testing machines: a review with reference to rock failure', Engineering Geology, vol. 6, no. 3, pp. 155-189.

Kaiser, PK \& Cai, M 2012, 'Design of rock support system under rockburst condition', Journal of Rock Mechanics and Geotechnical Engineering, vol. 4, pp. 215-227.

Kaiser, PK, McCreath, DR \& Tannant, DD 1996, Canadian Rockburst Support Handbook, Canadian Mining Research Organization, Sudbury, Ontario.

Kidybinski, A 1981, 'Bursting liability indices of coal', International Journal of Rock Mechanics and Mining Sciences Geomechanics Abstracts, vol. 18, pp. 295-304.

$\mathrm{Li}, \mathrm{CC}$ 2010, 'A new energy absorbing bolt for rock support in high stress rock masses', International Journal of Rock Mechanics and Mining Sciences, vol. 47, pp. 396-404.

$\mathrm{Li}, \mathrm{X}, \mathrm{Du}, \mathrm{K}$ \& Li, D 2015 'True triaxial strength and failure modes of cubic rock specimens with unloading the minor principal stress', Rock Mechanics and Rock Engineering, vol. 48, pp. 2185-2196.

Li, D, Li, CC \& Li, X 2011, 'Influence of sample height-to-width ratios on failure mode for rectangular prism samples of hard rock loaded in uniaxial compression', Rock Mechanics and Rock Engineering, vol. 44, pp. 253-267.

Linkov, AM 1996 'Rockbursts and the instability of rock masses', International Journal of Rock Mechanics and Mining Sciences \& Geomechanics Abstracts, vol. 33, no. 7, pp. 727-732. 
Manouchehrian, A \& Cai, M 2016 'Simulation of unstable rock failure under unloading conditions', Canadian Geotechnical Journal, vol. 53, pp. 22-34.

Martin, CD \& Maybee, WG 2000, 'The strength of hard-rock pillars', International Journal of Rock Mechanics and Mining Sciences, vol. 37, pp. 1239-1246.

Michelis, P, 1985, 'A true triaxial cell for low and high pressure experiments', International Journal of Rock Mechanics and Mining Sciences and Geomechanics Abstracts, vol. 22, no. 3, pp. 183-188.

Mogi, K 1962, 'The influence of the dimensions of specimens on the fracture strength of rocks: comparison between the strength of rock specimens and that of the earth's crust', Bulletin of the Earthquake Research Institute, University of Tokyo, Tokyo, vol. 40, pp. 175-185.

Mogi, K 1971, 'Fracture and flow of rocks under high triaxial compression', Journal of Geophysical Research, vol. 76, no. 5, pp. 1255-1269.

Ortlepp, WD \& Stacey, TR 1994, 'Rockburst mechanisms in tunnels and shafts', Tunnelling and Underground Space Technology, vol. 9, pp. 55-65.

Palmstrom, A \& Stille, H 2007, 'Ground behaviour and rock engineering tools for underground excavations', Tunnelling and Underground Space Technology, vol. 22, pp. 363-376.

Takahaski, M \& Koide, H 1989, 'Effect of the intermediate principal stress on strength and deformation behavior of sedimentary rocks at the depth shallower than 2000 m', in V Maury \& D Fourmaintraux (eds), Proceedings of the International Society for Rock Mechanics International Symposium: Rock at Great Depth, Pau, France, Balkema, Rotterdam, pp. 19-26.

Tao, YZ 1987, 'Rockburst and its criterion in highly geostress zone', Yangtze River, vol. 5, no. 25.

Wang, J. \& Park, HD 2001, 'Comprehensive prediction of rockburst based on analysis of strain energy in rocks', Tunnelling and Underground Space Technology, vol. 16, no. 1, pp. 49-57.

Wawersik, W, Carlson, L, Holcomb, D \& Williams, R 1997, 'New method for true-triaxial rock testing', International Journal of Rock Mechanics and Mining Sciences, vol. 34, pp. 3-4.

Xu, NW, Li, TB, Dai, F, Zhang, R, Tang, CA \& Tang, LX 2016, 'Microseismic monitoring of strainburst activities in deep tunnels at the Jinping II hydropower station, China', Rock Mechanics and Rock Engineering, vol. 49, pp. 981-1000.

Zhao, XG \& Cai, M 2015, 'Influence of specimen height-to-width ratio on the strainburst characteristics of Tianhu granite under true-triaxial unlading conditions', Canadian Geotechnical Journal, vol. 52, pp. 890-902.

Zhao, F \& He, MC, 2016, 'Size effects on granite behavior under unloading rockburst test', Bulletin of Engineering Geology and the Environment, pp. 1-15.

Zhao, XG, Wang, J, Cai, M, Cheng, C, Ma, LK, Su, R, Zhao, F \& Li, DJ 2014, 'Influence of unloading rate on the strainburst characteristics of Beishan granite under true-triaxial unloading conditions', Rock Mechanics and Rock Engineering, vol. 47, pp. 467-483. 
